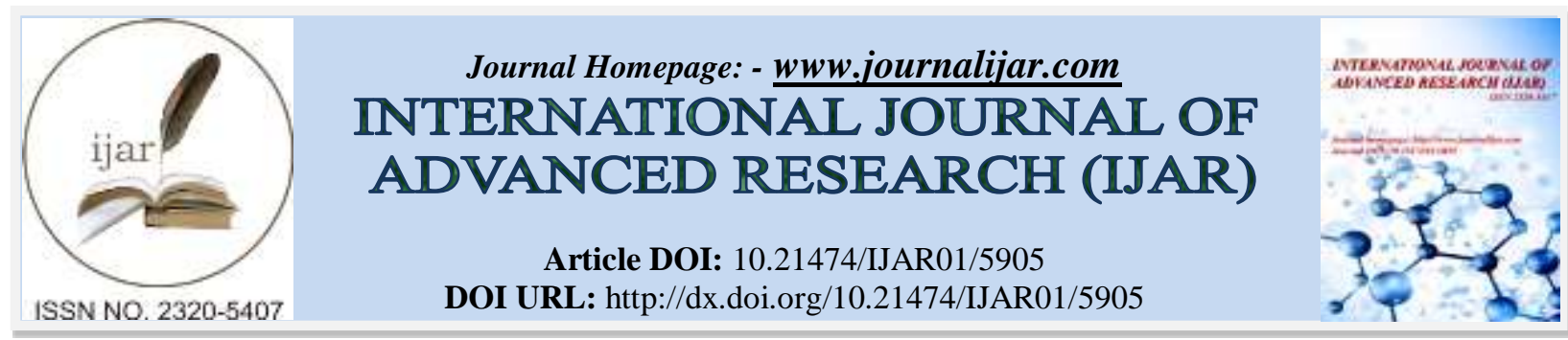

RESEARCH ARTICLE

\title{
THE INFLUENCES OF HABITUS CHANGE FROM FISHERMAN TO FARMERS TOWARD TRADITIONAL HOUSE TERRITORY IN THE CUSTOMS OF SENTANI PEOPLE IN PAPUA.
}

Deasy Widyastomo ${ }^{1}$, Muhammad. Faqih ${ }^{2}$ and Purwanita Setijanti ${ }^{2}$.

1. Doctoral Student, Department of Architecture, Institute Technology of Sepuluh November, Surabaya, Indonesia.

2. Department of Architecture, Institute Technology of Sepuluh November, Surabaya, Indonesia.

\section{Manuscript Info}

\section{Manuscript History}

Received: 18 September 2017

Final Accepted: 20 October 2017

Published: November 2017

Key words:-

Change $\cdot$ Territory $\cdot$ Habitus *

Sentani Indigenous People.

\begin{abstract}
framework of their knowledge, familiar ideas, and habits as personal experiences in a socio-cultural context (Bourdieu, 2002). Territorial behavior is a way to define boundaries that mark a form of privacy, and territorial behavior determines limits for personalized forms (objects and places) by means of communication and behavior of individuals or groups within a region (Altman, 1975). The change of fishermen's habitus to farmer's habitus becomes a phenomenon which causes changes in traditional territory of Sentani indigenous people. How the space territory in the traditional house of indigenous people on the change of fishermen's habitus to farmer's habitus becomes the subject of this study.

The research method used is a qualitative method, by doing interpretation study on the current conditions. The research results of habitus changes from fishermen to be farmers in Sentani indigenous people affect the territory change of traditional houses and settlements. The changes of traditional house are especially on the use of space territory. Space territories on traditional houses in fishermen's habitus and farmers' habitus have already used clear boundaries of fixed elements in creating territorial boundaries. The change of customary territory and sacred territory as the primary territory occurs in the farmer's habitus, which characterized by the presence of church and government in influencing norm, cultural and psychological aspects of indigenous people. On the territoriality of settlements, there is also a change in both fishermen's habitus and farmers' habitus, and both habitus have the same characteristic that is forming defence territory to protect the security and safety of indigenous people.
\end{abstract}

Copy Right, IJAR, 2017,. All rights reserved.

\section{Introduction:-}

Culture is closely related to the traditions of society. The tradition of setting space boundaries has an effect on human behavior. The space boundaries generated are as the impact of space requirements to accommodate behavior. According to Koentjaraningrat (1992), culture involves the whole system of ideas, actions and human products. This is an effort of humans as a result of self-learning in society. In everyday life, there is a presumption that culture is something relating to traditional behavior of a particular area. This habit is influenced by heredity. Thus, space can 
be defined as the acceleration of local culture, where the space formed in traditional settlement is an imaginary picture of the existing culture. This is important to show the form of culture in the context of spatial planning creation.

According to Pastalan (1970) in Yunita (2014), territory is a bordered space which involves psychological identification to a place, such as regulatory actions and attitude of possessing objects within the territory and having recognizable boundaries through behavioral change and the nature of privacy when the territory is accessible (Lang, 1987). Territoriality is a manifestation of someone's "ego" because he/she does not want to be disturbed, or it can be said to be a manifestation of someone's privacy. If we observe the environment around us, we will easily encounter human territorial indicators such as signboards, boundary fences, or boards showing ownership of a land. There is a negotiating process of the shared space (Somer R, 1969). According to Edney J (1974), territoriality is something related to physical space, signs, ownerships, defenses, exclusive use, personalization, and identity. This includes dominance, control, conflict, security, lawsuit, and defense. According to Altman (1975) in the theory of "Behavior Constraint" states that excessive or unwanted stimulation leads to obstacles in the processing capacity of information that result in a person losing control of the current situation.

Sentani indigenous people have unique traditional houses, and still exist today. One of traditional cultures as an architectural work that still survives and has unique characteristics, namely traditional houses located in Sentani residential neighborhoods in Sentani Lake. As said by Hartzler (1976) Sentani people traditionally live as fishermen, farmers, and sago harvesters and Sentani indigenous people are homogeneous societies that still uphold the tradition taught by their ancestors, one of which can be seen physically from the traditional houses of Sentani indigenous people. Culture changes in conjunction with the change of built environment. When the environment is built for homogeneous society groups and has control over the built environment, it can be seen in traditional societies (Rapoport and Hardie, 1991). Based on description above, the purpose of this research is how the change of space territory in fishermen's traditional house into farmers' traditional house influences cultural and environmental changes.

\section{Theoretical Review:-}

Culture is directly related to tradition that influences human behavior. According to Altman and Chemers (1984), culture is assumed as: first, beliefs and perceptions, values and norms, customs and behaviors of groups or societies, and including what they believe to be a belief in their lives. Secondly, culture is used to show cognition and behavioral feelings among people who share the same habits. Thirdly, culture describes beliefs, values; behavioral styles in everyday life in order to be understood especially for young generation. This value is to educate youths to preserve the habit of using time. These four values emphasize on beliefs and involve mental processes of community behavior. Culture was born in an object and physical environment such as house design, community layout, and public buildings that explicitly reflect cultural values.

Habitus is an intuitive practical reaction to situations based on experience and it constitutes spontaneity without consciousness or will (Bourdieu, 1990). Bourdieu's main concept on habitus can be said to be a mediation between structural factors and social practices. Bourdieu in the architectural context implies that the specific meaning of what people interpret on built environment is formed and restricted by what they know from their background, sociocultural experience and accepted ideas and circumstances prevailing in their contextual environment. Bourdieu's notion on the formation of meaning reveals how human views, past experiences or ideas, and socio-cultural associations with built environment play an important role in development as the transformation of architectural identity. (Bourdieu 2002). Lang (1987) argues that territory has four main characters namely, ownership or rights to a place, personalization or marking of a particular territory, rights to defend against external interference, and control of some functions. This starts from meeting the basic needs of psychological cognitive satisfaction and aesthetic needs. Brower (1976), argues that territoriality is a relationship of individual or group with physical arrangement, which is described by a sense of belonging and an effort to control the use of space. Concretely according to Brower, it is marked by the placement of territorial (dwellings) symbolically.

Altman (1975) divides territory which is associated with personal involvement, closeness to the daily life of an individual or a group, and frequency of use. The three categories are primary, secondary and public territory. 1. Primary territory, is an area which is owned, used exclusively, realized by others, controlled permanently, and becomes a major part in the daily activities of its inhabitants. 2. Secondary territory is an area that is not frequently used exclusively by a person or a group of people, and has a relatively wide area coverage and controlled 
periodically. 3. Public territory is an area used by anyone and it must comply with norms and rules applicable in the area. These three categories are very specific to be associated with the peculiarities of cultural aspects of its society. The concept of privacy and territory is closely related, but the definition of privacy is more emphasized on the ability of individuals or groups to control visual, auditory, and olfactory power in interacting with their fellows. The concept of behavior in the public space design greatly affects behavior in the public space because the formation of a wider territory of individuals or groups will also involve the territorial rights of other individuals or groups.

Factors affecting territory are personal characteristics, situational differences and cultural factors. Personal factors that affect characteristics of a person are gender, age and personality which are believed to have influences on territorial attitudes. Factors of situation are situational differences that affect territoriality. There are two situational aspects, namely physical and sociocultural order. Both situational factors play a role in determining territorial attitudes. Cultural factors are attitudes that affect territoriality. The differences in territorial attitudes are influenced by a very diverse cultural background. When a person visits a public space far beyond his/her culture, it will lead to different territorial attitudes. For example, an European came and visited Asia and he/she made a social interaction in the public space of country he/she visited, his/her territorial attitude would be very different. According to Altman (1975), the nature of territoriality is an innate trait and it proves the aggressive innate trait of human beings. The basic characters of a territory are about: 1. Ownership and place layout. 2. Personalization or territory marking. 3. Order to defend against disorders 4. Abilities including range of basic physical needs to cognitive satisfaction and aesthetic needs. According to Gifford (1987), territory is a space that can be defined and controlled by an individual or group through the use of physical space, ownership, defense which are exclusively used or spatial access-oriented identity signs.

It can be concluded that the formation of territory can be seen from 3 (three) categories, namely primary territory, secondary territory and public territory. The formation of territory involves personal involvement, closeness to the daily life of an individual or a group, and frequency of use. The four main characters of territory are ownership or rights to a place, personalization or marking of a particular territory, rights to defend against external interference, and control (functions). There are four characters to meet the basic needs of psychological cognitive satisfaction and aesthetic needs (beliefs and perceptions, values and norms, customs and behaviors of groups or societies).

\section{Research Methods:-}

Groat and Wang (2002), says that qualitative research is interpretation and meaning of the current or ongoing situation. Interpretation emphasizes the role of researcher as the main part, i.e. as the "objective eye" of research instrument. Data is obtained by conducting observations, open questions, and interviews at the natural setting, and focused on respondents' way of thinking. Methodology used in studying environmental and cultural changes is by trying to build the foundation of traditional environments and cultures through the order of how environments formed from time to time and to identify the core of traditional defensive elements, changing, disappearing and new elements (Rapoport and Hardie, 1991). Research method used in this research is based on 3 (three) steps of investigation to seek the change of cultural and architectural relationships at different residences (fishermen's habitus and farmers' habitus). The 3 (three) steps of investigation are as follows (1). To review past historical documents (reference of 1903) and previous studies, and criticism to find the authentic basis for the existence of Sentani indigenous people; (2). To collect the oral history and collective memory through interviews and observation methods to collect various opinions, as well as the development of historic traditional houses and vernacular heritage on traditional cultural life; (3). To conduct direct observation method, to improve the reliability of research by a case study method.

\section{Research Results:-}

The territory of Sentani indigenous people formed in the traditional settlements is studied based on three categories, namely primary, secondary and public territories. These three categories are associated with personal involvement, closeness to the daily life of an individual or a group, and frequency of space use. (Altman, 1975). Territoriality is the extent to which living organisms define territory and defend it, especially from the possibility of intervention or other party's aggression.

Interpretation of Sentani Territory at Ayapo Village in 1903 is described in Figure-1 below. 


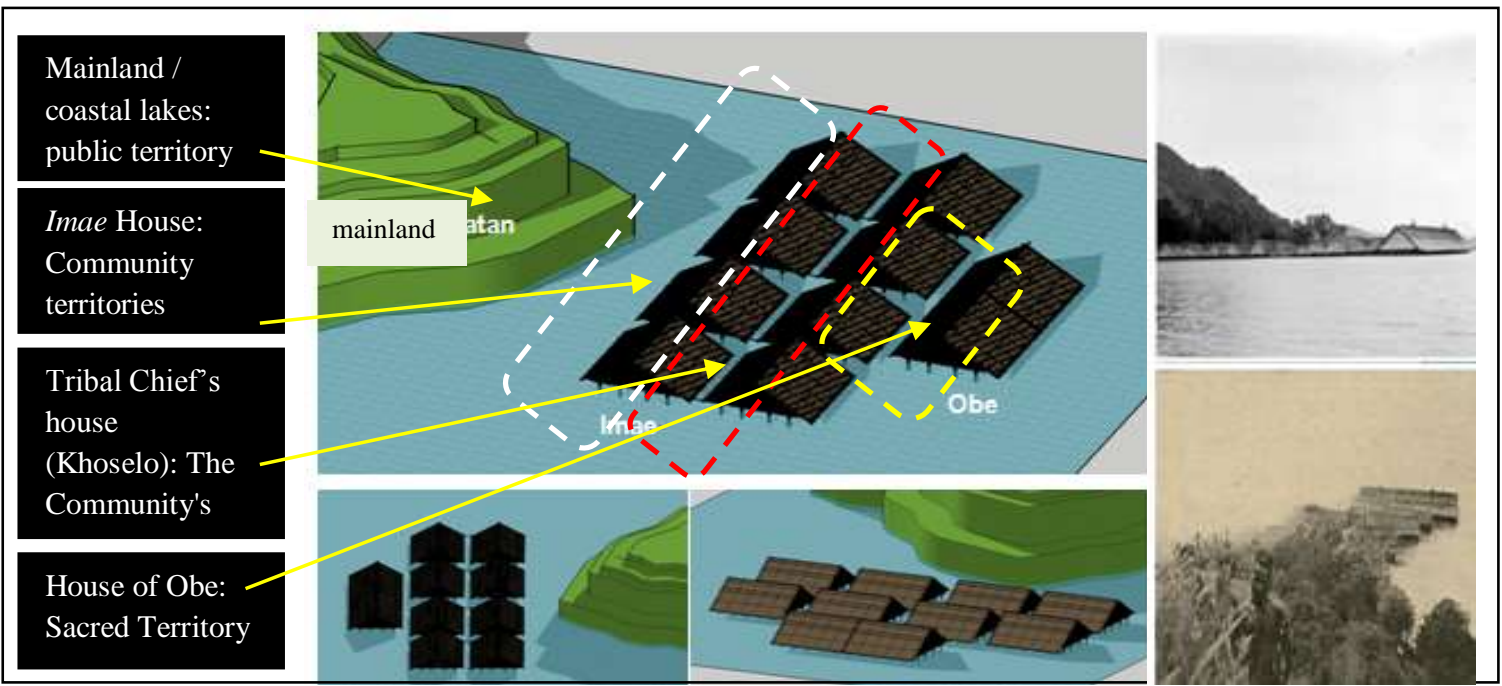

Figure 01:- Interpretation of Sentani Territory in Kampung Ayapo in 1903 (Sande,1907, author, 2017).

In the search of historical references of 1903 and the interview results with the traditional leader of Ayapo Village, it is found territorial boundaries of traditional houses and settlements of Sentani indigenous people. The territorial boundaries of Ayapo Village (1903) consist of lakes, coastal areas and hills as borders of customary territory. The position of Obe house has a strong role in the territory of settlements as the center of customary government and led by Ondoafi (the highest customary leader). Territory is a space whose utilization is controlled by individuals/groups through the use of physical space, in which the use and utilization of space are based on agreement and surveillance (Gifford, 1987). Sacred territory is prime territory, and lies in the Obe house area. Sacred territory is understood by Sentani people as a physical territory, and it also includes non-physical territory. This is caused by the perception and treatment of indigenous people to Obe house as a sacred territory. The customary primary territory lies in Obe house area while Ondofolo mansion house and tribal chief's house are symbols of ancestral spirits' existence. Obe house is the initial place of youths in learning custom and a place of war training, in defending their settlement area.

Indigenous community territories are devoted to Imae house area. Imae house is located at the back of Obe house and Khoselo house (tribal chief). Community territory is a shared space territory. Community territories are used jointly by all indigenous people. Community territories are located in a community house that is a mansion house. The mansion house is used for a large family residence from clan groups. These territories are used exclusively and have a wide range controlled by parents and the eldest son. The orientation of building overlooks a lake to anticipate attacks from enemies. Characteristics of space territory in 1903 took the form of groups in a single customary cluster of which is so-called as a customary defense space. Territoriality of space in the form of groups uses space for activities/ interactions, and the mainland space is used as public territory. Public territory as community territory is located on the coastal plain of lake. Male and female are separeted during the use of public territory for both community's parties and traditional events. The separation of women's territories and men's territories is divided by clan groups led by respective tribal chiefs.

In the process of determining territories, it is determined by the respective tribal chiefs as leaders who make territorial decisions, in which the chief first coming to sit will show his territories for men, whereas the women's territories are determined by the wife of tribal chief or a woman who is respected in the custom. This shows that in the context of indigenous people, forming and using territory space are based on ways and ideas of indigenous peoples' thinking. The way of thinking about traditional knowledge and custom in an effort to adapt socio-cultural experience in maintaining the existence of custom in the built environment is done spontaneously in the contextual environment. Special meaning on the determination of territory in the traditional settlements of indigenous people in 1903 is formed from way of thinking, knowledge and socio-cultural experience of Sentani custom which are based on beliefs in customs and ancestors as the power that governs and protects them against intervention of external environment.

Interpretation of public territories in 1903 is described in figure-2 below. 


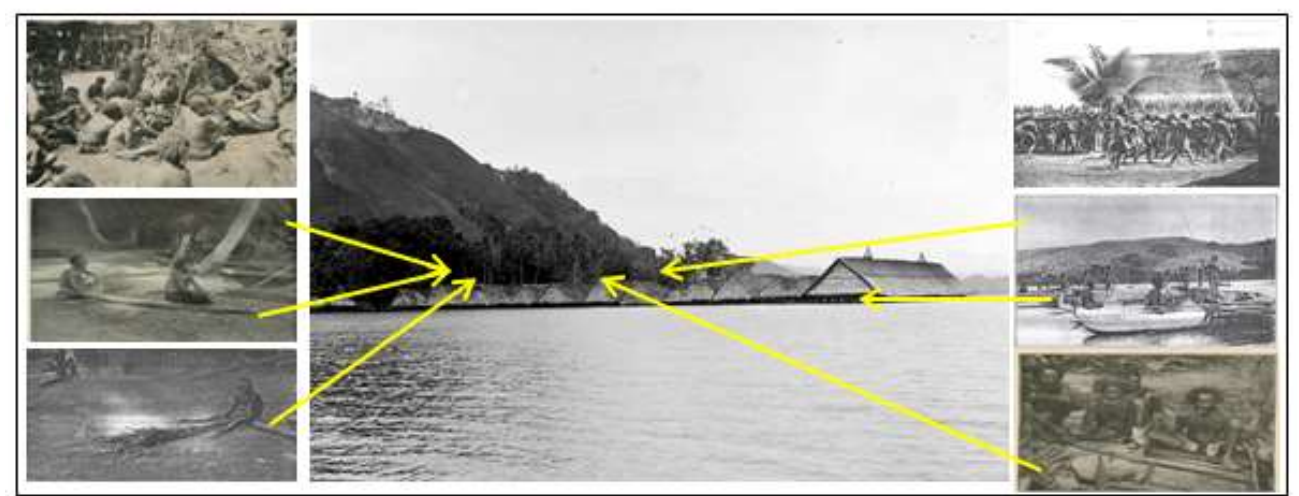

Figure 2:- Interpretation of Public Territories in 1903: Customary Party Activities, Smoking, Betel Nut Chewing, Fishing, Making Fabrics from Bark (Sande, 1907, author, 2017).

Characteristics of traditional house territory in Imae house are influenced by the norms, cultural, and psychological aspects of its inhabitants in the formation and use of 'space', as said by Rapoport (1969). The formed Sentani community culture is centered on customary activities and beliefs to ancestors, in arranging and using Imae house space. Imae House is a mansion house occupied by families of approximately 4-6 family heads. The "Imae" mansion house is headed by tribal chiefs (Khoselo) or the oldest indigenous man. Imae house as a mansion house is devoted as a residence or family house inhabited by parents, children and unmarried girls. While special for boys who are still single live in Obe house. Boys live at Obe house to learn indigenous life and practice to war in an effort to maintain the security and safety of village. In the use of space in Imae house in 1903, the people formed and used space territory based on people's perspective on the position of custom as the main element. Ways of thinking and experiences of their parents or ancestors in using space territory are based on the parent's perspective as the homeowner. The house has spaces that have no boundaries or called imaginary rooms. In addition to parents, the eldest son has the same rights as the parents. This is because the eldest son is the heir or successor of parents and as the next customary leader.

Interpretation on the use of space on Imae house in the fishermen's habitus is described in Figure- 3 below.
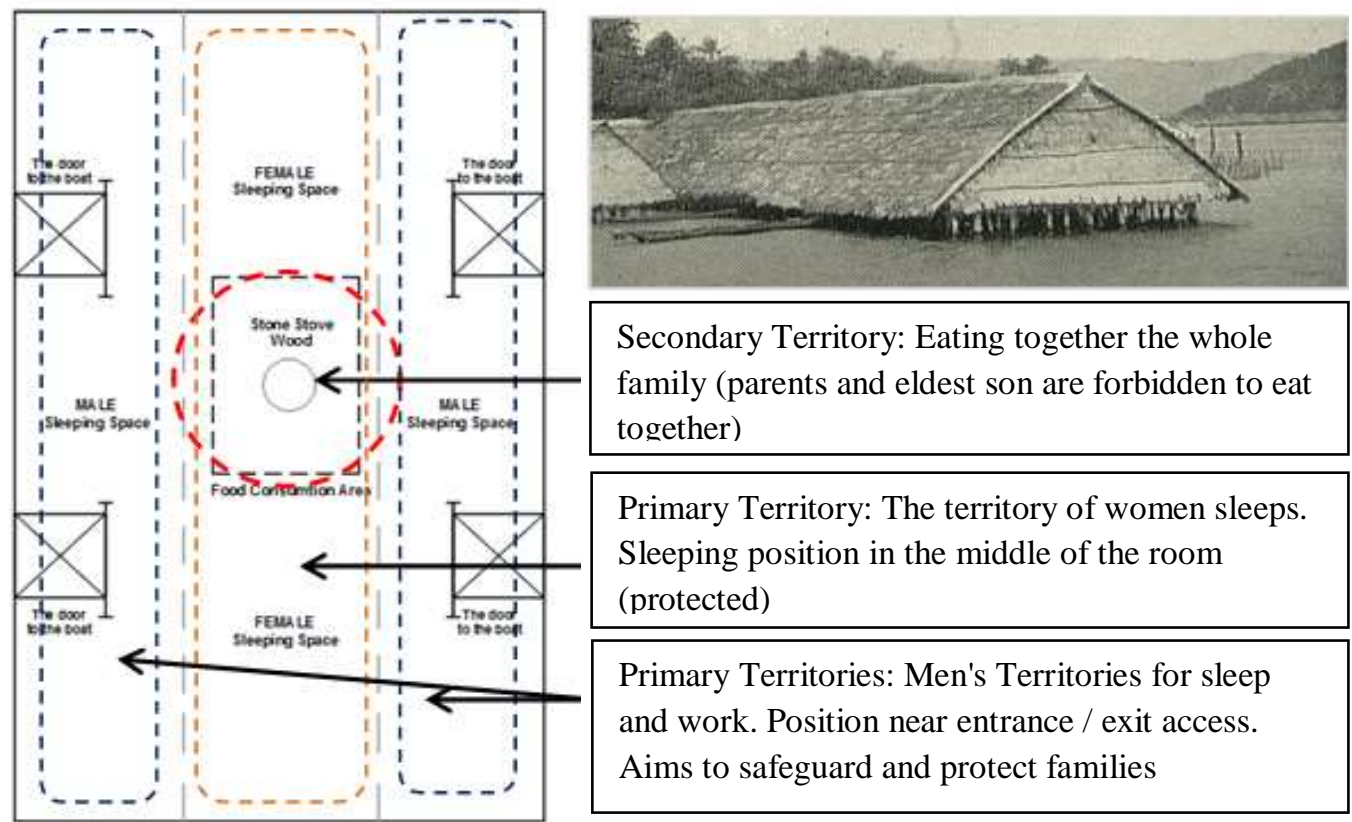

Secondary Territory: Eating together the whole family (parents and eldest son are forbidden to eat together)

Primary Territory: The territory of women sleeps. Sleeping position in the middle of the room (protected)

Primary Territories: Men's Territories for sleep and work. Position near entrance / exit access. Aims to safeguard and protect families

Figure 03:- Interpretation of Imae space (Sande, 1907, author, 2017)

Space territory in Imae house does not have room divider or can be called as an imaginary room. In everyday life, the occupant's activity system from starting to work, play and circulate in the house, can be done in any room. This 
is because all occupants can access all parts of space. While at bedtime, there will be primary territory that separates men and women. The men's primary territory is located near the exit access in anticipation of enemy attacks in order to get out quickly. Women's primary territory is close to the fireplace (cooking activity) located at the center of Imae house space which gives a protected meaning. The boundaries of territory are bordered by the restrictions of each behavior, in which each actor knows the area where they do activities and take a rest. All of the activities are in Imae house.

Imaginary room in Imae house can be used for various activities, either playing, studying, gathering or working. Such activities can be done in all spaces. While for cooking, eating and sleeping activities, the territory has been naturally formed from the people's perspective on the territory. The territories are created by how communities or family members see, hear and feel the functions of each space as a place to do a particular activity. This is based on parental regulatory norms in determining the positions of an activity which will be performed.

The results of research in fishermen's habitus in Ayapo village show that the use and utilization of space in the residence are regulated by the tribal chief and parents as the main owner of Imae house. While the use of outdoor space among community users, all community activities are controlled by Ondoafi as the highest customary leader. The territorial boundaries of Ayapo village housing consist of Obe house, Imae house, community house and Church. The position of Obe house does not become the orientation of Imae community houses and Church anymore, as happened to fishermen in 1903. Primary territory or sacred territory is found in Obe house area, which is understood by Sentani people as physical territory and non-physical territory. Obe house is considered and treated by Sentani indigenous people as a sacred area if it is viewed from the way and usage patterns as a place for supreme customary leaders, as said by Zeizel (1981), the shape of space only tends to affect how space is used and the pattern of activities occurring in the space.

Customary territory of Ayapo Village is described in Figure-4 below.

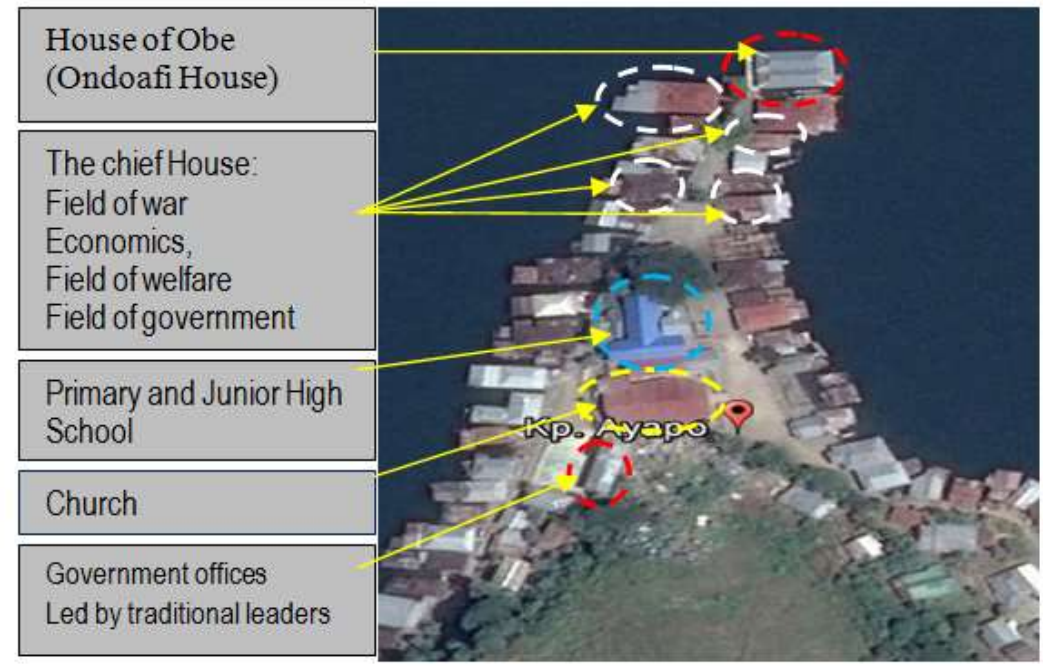

Figure 04:- Customary territory of Ayapo Village (Google Earth and Author 2017)

Indigenous community territories are devoted to mansion house of tribal chiefs. Community territories are shared territories used by the community, located in church areas, schools, government offices (village hall) and residential courtyards. These territories are used exclusively, and have a wide scope controlled by custom in their use and activity. Community territories are used by the community on a regular basis, ie for customary activities, spiritual activities and sports activities. The orientation of Church, elementary and junior high schools buildings facing the sun implies a sunrise that the land of Papua is the beginning of sunrise.

Characteristics of space territory in Ayapo fishermen's settlement in Sentani Lake have a clustered form which forms a unity of customary clusters. Territoriality of space in the form of a centralized group utilizes the environment and road as a space for activity/interaction. This is caused by limited land, so that residents use yard or field to do daily activities/interactions as well as religious and customary activities. Because the shape of space tends to affect how the space is used and patterns of activity occurring in the space. The shape of square space tends to 
have concentrated activities. The characteristics of space territory of Sentani indigenous people in Ayapo Village consider the norm, cultural and psychological aspects of indigenous people which influence the formation of centralized 'space' as traditional fishermen's settlements. The Ayapo Village is a traditional village of Sentani tribe led by Ondofolo and tribal chiefs as the indigenous Khoselo. The community culture formed by custom and living in a strong customary order regulates life activities and home land use. While activities that occur in the communities are regulated and controlled by their respective tribal chiefs with the supreme leader of Ondoafi.

During the observation in Ayapo Village especially in Imae house, it is found that Imae house is inhabited by large families consisting of 4-6 family heads. The mansion house "Imae" is headed by respective chiefs (Khoselo). Imae House as a mansion house is devoted as a residence or family home. The inhabitants of the mansion house usually consist of children, women, and men who have not and have been married. The division of space territory for each family head consists of a room and a kitchen as primary territory, whereas hall and living room are used together. The primary territory on Imae house, rooms and kitchens, used by each family head is an exclusive area. The area is recognized by other inhabitants and controlled permanently by the head of family. This area is a major part for the daily activities of its inhabitants. In Imae house, secondary territory is created in the living room and boat mooring area behind the house. Secondary territory is not used exclusively by the inhabitants, but the use is jointly controlled by all inhabitants and controlled by the eldest son or parents. While area serving as a public territory occurs in the living room/hall that can be used for all household activities and accessible to the whole family but must comply with the norms and rules applicable in Imae house.

The Division of Imae Territory in Ayapo Village is described in Figure-5 below.

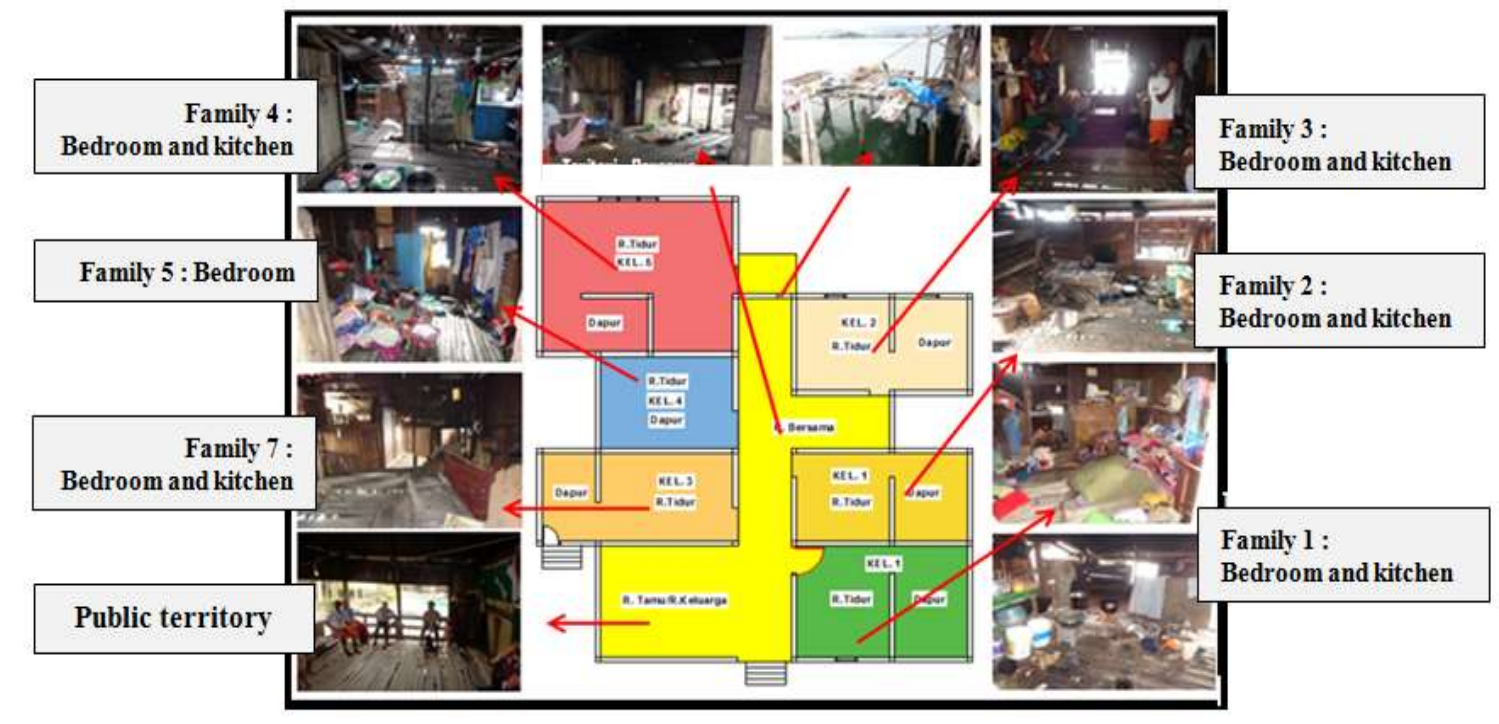

Figure 05:-The Division of Imae Territory in Ayapo Village (survey, 2017)

The territory boundaries of Imae house have fixed boundaries. Fixed boundaries appear in the use of architectural elements ie the use of house walls, doors, curtains that limit the territory of each family. The fixed elements become clear boundaries and as limits to privacy of each family head. The orientation of Imae house in Ayapo Village overlooks the mainland and overshadows the lake. This is because the back of house is used as a boat mooring area, food storage, other materials such as wood, nets, and to bind the boat. The territories created have fixed boundaries to separate activities and the controlling is done individually. The controlling of spatial use is done individually where the utilization and use of space are based on agreement and surveillance along with the inhabitants of the house.

In the fishermen's habitus of Ayapo Village, the specific meaning arising as the perception of Sentani indigenous people to form the built environment is to protect the indigenous people of their group. In the fishermen's habitus of Ayapo Village, they still believe in the spirits of ancestors, and it becomes part of public belief but not become an absolute belief. The beliefs of majority of indigenous people in Sentani Village is Christian. It is characterized by the various Christian beliefs existing within the society. The coming of Christianity has changed the pattern of 
community life with the recognition of women position in the social life of society. This can be seen from the sitting procession in the church worship room. In church, the procession or how congregation sit is divided into two groups of men and women. This is the perspective of indigenous people to think in traditional knowledge and experience of believing in God which is brought into their socio-cultural life experience in a contextual environment, and alongside with custom.

The observation results on the existing farmers' habitus of Kehiran Village in Sentani mainland to the use of space territory are as follows. Kehiran Village is the first village that migrated to Sentani mainland. Kehiran Village migrated to the mainland in an effort to open agricultural land. The migration was made in 1970 led by Ondoafi. Kehiran Village is led by Ondoafi and assisted by several tribal chiefs as indigenous koselo. The culture of Kehiran society is centered on customs, both from lifestyle, home and agricultural land uses. All community activities customary to be used for the welfare of indigenous people. Activities occurring in the community are regulated and controlled by respective tribal chiefs.

Territories of Kehiran Village settlements are formed on the basis of openness. Openness is characterized by three pillars, namely custom, church and government. Territories of residential space is a space whose utilization is controlled by Ondoafi and assisted tribal chiefs (khoselo) in the use of physical space. The boundaries of customaryl territory are limited by the presence of Ondoafi house and Obe house as the center of indigenous activities. The houses are located in a territory that is protected by customary functionaries such as tribal chiefs (Khoselo), warlords, head of economics (welfare) and other fields. While the elements of government and church which are the supporting elements of community activities are located in the middle of settlement, that is located at the entrance area of Kehiran housing. This shows that Church and government are 2 (two) important supporting elements in life and become pillars of customary companion pillars. The three pillars, ie custom, church and government have building orientation facing to east, which is toward sunrise. The orientation implies a meaning as the beginning of life activity.

Territories of Obe House, Government, Religion in Kehiran Village are described in Figure-6.

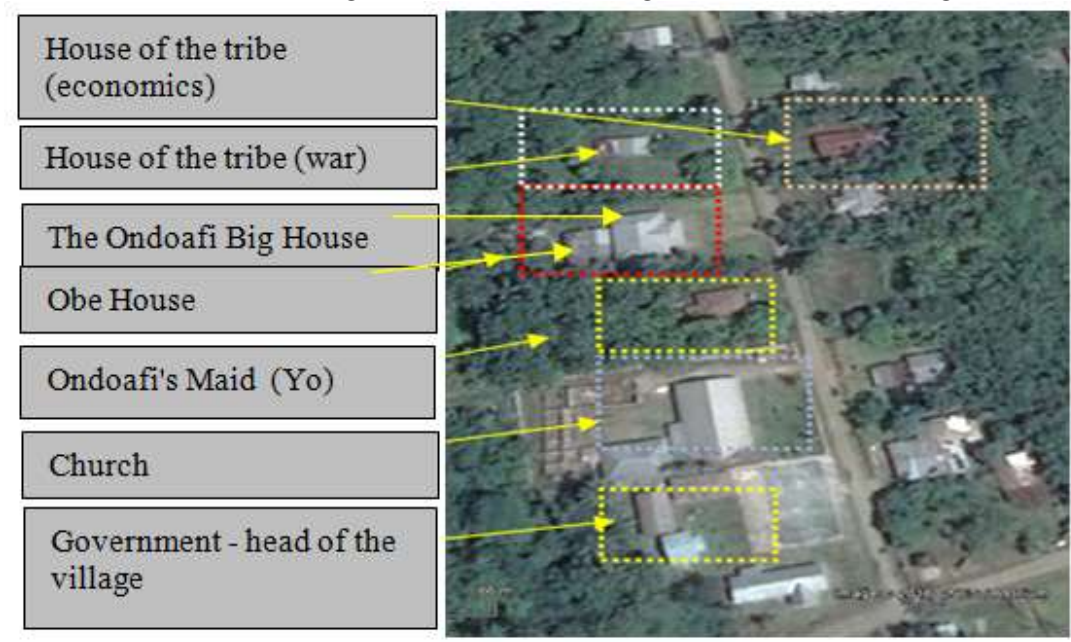

Figure 06:- Territories of Obe House, Government, Religion in Kehiran Village (survey, 2017)

In Kehiran Village, Obe house and Ondoafi house are not considered as sacred territories. This is because the Obe house and Ondoafi do not use customary element "Yuniki" as the greatness of custom. According to Ondoafi, Kehiran Village is a sign of openness to accept all elements of society in Kehiran mainland. The primary territory lies in Obe house which is understood by Sentani people as physical territory and non-physical territory, where in the manner of perception and treatment, it is a customary territory which is respected. While territories of indigenous communities in Ondofolo mansion house and tribal chiefs are as a place of group activities in customary ritual activities. The ritual activities which are still performed by custom, are wedding, death and birth events. The community territory, which is a shared territory, is used by the community located on the residential yard of Ondofolo and government offices. Community territory as the territory of customary activities is devoted to the activities of men located in the area of government offices. Whereas the community territory for women is in Ondosfolo mansion house. These territories are used exclusively and have a wide range controlled by custom. The 
community periodically uses the space and it is a secondary territory whose control of its surveillance conducted by custom (Ondofolo).

Characteristics of space territoriality in the settlement of Kehiran Village is in the form of linear. The shape of space tends to affect how the space is used and the patterns of activity occurring in the space. The shape of space is elongated (linear) and the activity tends to disperse (Zeisel, 1981). The linear space territory is a settlement that uses road as a space to do activities and interact with other communities in the environment. The orientation of buildings and government offices overlooks toward the village road. Road in the village environment has a road width of six meters and it is accessible enough for communities to do their daily activities either to garden or to work. The house of indigenous people as the cover of space which limits space and the linear space territoriality causes the distance to the relative space closer and easily reached by all elements of society.

In Sentani indigenous farmers, the house shapes are different but the width of garden area has clear boundaries between one house to another. Indigenous people receive a land area given by custom. The division of land is divided equally among indigenous people i.e. 30 x 75 meters. This makes a regularity of residential area in Kehiran Village. Land given by custom can be used by the communities to build houses and gardens. In farming activities, the communities are given freedom to manage the garden in accordance with their respective ability to farm or grow crops. Customary land used is not allowed to be sold because it is communal title (hak ulayat). The characteristics of space territory of Sentani indigenous people in Kehiran Village consider the norm, cultural and psychological aspects of society in influencing the formation of 'space' controlled by custom and government. Residential homes in Kehiran Village on average have a family structure consisting of 1-2 family heads. This is people's perspective to turn into a prosperous family. This is apparent from the house shapes in Kehiran Village which are the houses of nuclear family, single house-shaped house.

The Division of Space in the Residential Home of Kehiran Village is described in in Figure 7 below.

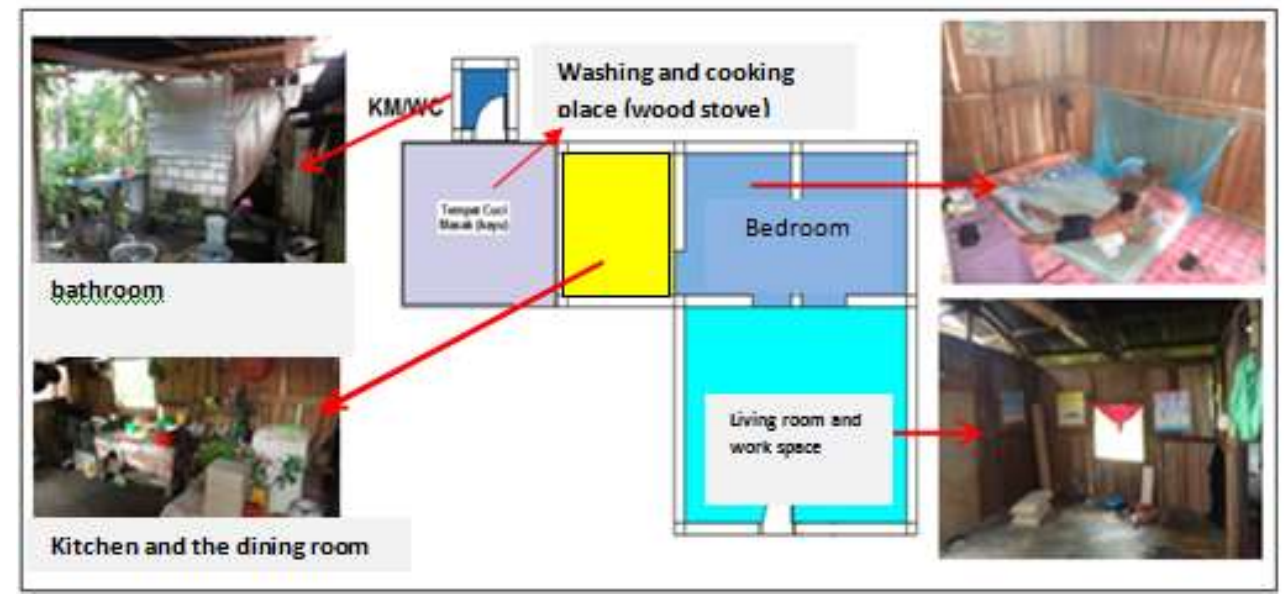

Figure 7:- The Division of Space in the Residential Home of Kehiran Village (survey, 2017)

On residential home in Kehiran Village, the primary territories are in rooms and kitchens. Rooms and kitchens are used by every head of a family which is an exclusive area that is controlled permanently by the head of family. Rooms and kitchens are major parts of inhabitants' daily activities. On residential home in Kehiran Village, the secondary territories are created in living room functioned as family room and work space. The living room is not very used exclusively by the inhabitants. While the area that serves as a public territory is located in the laundry room and bathroom, which are used together with other families. Other different families must obey the norms and rules controlled by parents and the eldest son. Personal factors of Sentani indigenous people influence one's characteristic. Personal factors such as sex factor of inhabitants, age and personality have an influence on the attitude of territoriality. This is apparent in the residential home. The territory formed is the influence of parents' personal factors in protecting and keeping the family safety with clear space boundaries. These boundaries are fixed elements i.e. walls, doors, curtains and windows.

In the context of farmers' habitus, the specific meaning in the current traditional settlements, perspective, community knowledge and personal experience formed in the built environment are ways of people think to prosper 
the family (nuclear family). Farmers' habitus still provides protection to indigenous people but it not a major element. In farmers' habitus, indigenous people have faith in God and this is a key element in people's lives. This is evident from the background of indigenous people who have faith in God and it is brought in the experience of socio-cultural life in their contextual environment. This can be seen from the way men and women live in the family ark which changed to be better. One of them is blessing of the church and custom becomes the official marriage procession of society.

\section{Conclusions:-}

The formation of territory on indigenous people is influenced by the position of custom as the holder of supreme power. The holder of supreme power is led by Ondoafi and assisted by tribal chiefs (khoselo). Changes in traditional houses and settlements from fishermen's habitus to farmer habitus in Sentani indigenous people have changed the territorial order which occurs in the use of indigenous people space, especially in primary, secondary and public territories. Territorial order exists especially in the space of residential home and traditional settlements.

Customary territory is the primary territory. On the change from fishermen's habitus to farmer habitus, the primary territory did not change (fixed). Fixed customary territory forms boundaries of territory in the settlement patterns. The boundaries of customary territory in the settlements are formed due to the presence of Ondoafi house and houses of Khoselo/ tribal chiefs. Customary territories, especially on land territories designated for houses, agricultural land and environment both in fishermen's habitus and farmer habitus are all under customary possession (Ondoafi and tribal chiefs) which constitutes communal title (hak ulayat). In customary activities, public territory remains unchanged (fixed). The unchanged public territory is on space territory between men and women. The territory created separates the territory of men and women in every customary event and activity. Customary territory has changed in the fishermen's habitus and farmer habitus, namely by the inclusion of church giving meaning of community life to accept the position of women in activities and social life. While the inclusion of church and government in farmer habitus gives a meaning of openness to outside world, for example they accept the position of women and the whole society including migrants in the customary territory.

Space territory in traditional houses has changed. On the territory of traditional house in 1903, the use of primary, secondary, and public territories is conducted in a space with no borders (imaginary), so the role and ability of inhabitants to control the visual, auditory, and olfactory power in using the space while interacting with each other at home are essential. In traditional houses, fishermen experience a change of territory in a residential space by using border or separator between rooms or fixed elements (doors, windows, curtains and walls). This is influenced by the formation of family structure, privacy and basic needs in Sentani indigenous people. These changes led to changes in the house shapes of indigenous fishermen to be better. While in the farmers' house, the residential territory also experienced a change. Changes in the use of space territory are influenced by family structure, privacy and basic needs and the increasing social relations of the occupants. These changes led to changes in the house shapes and the organization of space.

Changes in the habitus of Sentani indigenous peoples from fishermen to farmers led to changes in the territory of traditional houses and settlements in homogeneous indigenous people. Changes in community territory did not occur as a whole but fixed territory is still found, especially customary territory (primary territory). Changes in territory are affected by changes in family structure, privacy, basic needs, identity and social relations of residents in the community. Farmers' traditional houses on Sentani mainland have functions as personal or individual homes. While fishermen's traditional house is a representation of property owned by large family clan group (ancestors). This affects the personal attitude and role of society to determine the territorial attitude on the use of fishermen's residential space as heritage of ancestors to be unchanged.

\section{References:-}

1. Altman I, dan Chemers, M, Culture and Environment, Monterey, California : Brooks Cole. (1984).

2. Altman, I. 1975, The Environment and Social Behavior. Monterey, CA: Wadsworth.

3. Brower, S.N., 1976, Territory in Urban Settings. Dalam Altman, (1980), HumanBehavior and Enviroment. Plenary Press, NY and London.

4. Brower, S.N., Territory in Urban Settings. in Altman, (1980), Human Behavior and Environment. Plenary Press, NY and London.(1976) 
5. Faqih, Muhammad (2005), Domestic Architectureand Culture Change, Re-ordering the Use of Space in Madurese Housing. Thesis Doctor of Philosophy University of Newcastle

6. Gifford, R, (1987), Environmental Psychology : Principle and Practice, Boston : Allyn and Bacon. Inc.

7. Groat, L. \& Wang, D. (2002). Architectural Research Methods. New York: John Wiley\& Sons. Inc.

8. Haryadi, Setiawan.B , 1995, Arsitektur Lingkungan dan Perilaku, Proyek Pengembangan Pusat studi Dirjen Dekbud. Yogyakarta.

9. Koentjaraningrat, (1992), Kebudayaan dan Mentalitas Pembangunan. Gramedia Pustaka Utama Jakarta.

10. Lang, J., Creating Architectural Theory: the Role of the Behavioral Sciences in Environmental Design. New York: Van Norstrand Reinhold.(1987).

11. Laurens,J.M, 2004, Arsitektur dan Perilaku Manusia, Grasindo, Surabaya.

12. Sommer, Robert. (1969), Personal space : the behavioral basis of design / Robert Sommer, Englewood Cliffs, N. J. Prentice-hall.

13. Yunita Dwi A, Indah Widiastuti (2014), Kajian Ruang Liminal pada Konsep Teritori Pemukiman Adat Sunda Cigugur melalui Analisis Ritual "Ngajayak", Temu Ilmiah Iplbi, Prosiding Temu Ilmiah IPLBI.

14. Zeisel, J., 1981, Inquiry by Design: Tools for Environment-Behavior Research. Cambridge University Press, Cambridge. 